\title{
Introduction: The Question of Legitimacy
}

Talk of constitutional crisis conjures up some great disturbance in the larger society-revolution or war, economic depression or massive movement for social change. The mighty social forces unleashed by these events disrupt existing constitutional arrangements and threaten to overwhelm political and legal elites. The question, simply put, is whether existing leaders can channel these forces into constructive forms, or whether the Constitution will be fractured beyond recognition.

But there is another kind of crisis - generated not by social pressure but by the machinery of government itself. Some part of the machine misfires, then another, then another. The general public is bewildered, the elites are uncertain about the next step.

Time marches on-decisions must be made, they are made, and then?

Anxious reappraisal, followed slowly by a consensus on how the system performed. If the collective judgment is positive, the participants

Many thanks are due to Dean Tony Kronman, of Yale Law School, who provided financial support for the talkfest as part of the university's celebration of its tercentenary. 
celebrate the glories of their constitutional inheritance and look forward confidently to future challenges.

But if it is negative, a gnawing sense of illegitimacy eats away at the fabric of mutual confidence.

Consider Watergate. No great social force generated this crisis. Nothing compelled Richard Nixon to bug the headquarters of the Democratic National Committee. But he did, and the question was how the rest of the system would respond. Each step was controversial -from the congressional hearings to the discharge of Special Prosecutor Archibald Cox to the Supreme Court's decision to the president's resignation to his pardon by President Ford. Yet after the smoke cleared, and after much debate, a clear consensus emerged: the system worked, not perfectly, but well enough.

Will we be saying the same thing about Bush v. Gore? Or will the decision cast a darkening cloud over the Bush presidency and the Supreme Court of the United States?

The answer begins, but does not end, with the legal merits of the majority's decision. Part One of this book, "The Rule of Law?," opens with a spirited pair of essays by Charles Fried and Jed Rubenfeld. A professor at Harvard Law School, Fried confronts the decision on the basis of a distinguished career that includes service as solicitor general under Ronald Reagan and as associate justice of the Massachusetts Supreme Court. He argues that the Court's decision was entirely reasonable-it is the harsh academic reception that is extreme. Professor Rubenfeld of Yale Law School then enters the field with a powerful essay that exemplifies the emerging critique.

Both writers aim for a large audience and set the tone for the book. The contributors refuse to hide behind mind-numbing legal minutia, presenting the key questions in straightforward terms. You don't have to go to law school to get to the heart of their dispute. It is enough to be a thoughtful American.

This initial exchange is followed by two writers whose special experience deepens the debate. Professor Laurence Tribe's role as Al 
Gore's counsel before the Supreme Court is part of a unique career as the leading scholar-advocate of his generation. Judge Guido Calabresi, formerly dean of Yale Law School, is the most distinguished academic appointed by President Clinton to the United States Court of Appeals.

Tribe describes how television transformed the Court's perceptions of the stakes. Intervening without an adequate legal record, the justices allowed TV images to create a false sense of crisis and to distort their understanding of the constitutional requirements of equal protection. Tribe places the Court's decision in a real-world context, revealing the bankruptcy of its media-driven formulations. No less troubling is the Court's imperative need for order and its disdain for the political branches. He argues that the Court was wrong to assume the decisive role the Constitution assigns to Congress in electoral disputes and concludes with the fear that the decision may become "our judicial Vietnam"-undermining confidence in the judiciary even when major interventions are actually required by constitutional principle.

Judge Guido Calabresi begins with a sketch of three possible opinions that might have resolved Bush v. Gore in a principled way-one favoring Bush, one Gore, and one indeterminate at the time the Supreme Court decided the case. The trouble is that the Court failed to take any of these models seriously, awarding the presidency without committing itself to any coherent constitutional principle. Calabresi is no absolutist, and concedes that unprincipled decision making may sometimes be acceptable, even wise. But the problem confronting the Court did not remotely authorize such a breach with established judicial norms. It is only by committing themselves even more firmly to legal principle that federal judges may ultimately undo the harm caused by the aberrational character of the Supreme Court's decision.

We are reaching a crucial question: Is Bush v. Gore just another controversial decision, or does it represent a decisive breach with the rule of law? Owen Fiss of Yale Law School vigorously rejects the more disturbing answer. On his view, the case is no different from many 
others decided by the Rehnquist Court. He rejects the claim that its unprincipled character places the decision "on a different moral plane." Fiss believes that the Court's decision is principled. While he considers those principles to be mistaken and wrongly applied to the facts, he maintains that this is true of many decisions reached by many courts. The fallibility of judicial reason should not shake our collective faith in the rule of law, and in the judicial effort to hold power accountable to principle.

Robert Post and Margaret Jane Radin take a darker view. For Post, a professor at the University of California at Berkeley, the decision "conspired to inflict a searing and disorienting vision of a world without law, a nation subject to courts who command without accountability." Even as passions cooled over the following months, the case continues to pose the ultimate question confronting all teachers of law. If they present Bush v. Gore in classroom discussion as an ordinary, if flawed, decision, this may merely confirm their students' most cynical suspicions about the legal process. Is it not wiser to announce that the Supreme Court's decision was a fundamental breach with the rule of law, and challenge the next generation to place our national commitments on a firmer foundation?

Stanford's Margaret Jane Radin understands the fundamental question in similar terms but provides a more straightforward answer. Americans will never reconstruct the rule of law unless we candidly recognize how profoundly it was shaken by the Supreme Court's decision. As professionals most concerned with the future of constitutional development, law professors have an obligation to speak these uncomfortable truths to the larger public.

For all its themes and variations, Part One focuses on a tightly interconnected set of questions: Does Bush v. Gore have a solid-or even plausible-foundation in legal principle? If not, how to reestablish the nation's confidence in the rule of law?

Part Two, "Political Questions," confronts this legalistic focus with a series of political issues-beginning with the authority of the Court 
to oust politicians from the center stage of the electoral process. Professor Steven Calabresi sensitively explores the ways in which political efforts to break the "tie vote" in Florida were systematically discredited in the media, while judicial efforts were consistently glorified. Calabresi juxtaposes this pro-judicial bias of the media with the classical legal principles governing the "political question doctrine." $\mathrm{He}$ concludes that the Court had a constitutional obligation to defer to the political branches, and that it was up to Congress, not the Court, to resolve the ultimate conflict. Calabresi is one of the founders of the Federalist Society and an advisor to George W. Bush's campaign; his challenge to the Court is to be taken with special seriousness. Whatever else one may say about it, his defense of politics doesn't seem to be politically motivated!

According to Jeffrey Rosen, Calabresi is very much the exception. The most striking fact about the decision is how politically polarizing it is. If the Court is to save the rule of law, it must rethink its approach to political questions. Rosen traces the way the classical doctrine of principled restraint, elaborated by Calabresi, has been transformed into an invitation to judicial heroism. He challenges this new doctrine by confronting one of its primary defenders, Judge Richard Posner. Posner's efforts to defend Bush v. Gore on "pragmatic" grounds only demonstrate how speculative and dangerous the new interventionism has become.

Both Calabresi and Rosen seek to save the rule of law by reviving the political question doctrine. Mark Tushnet, in contrast, evaluates the decision in explicitly political terms. There is nothing particularly surprising about "five Republican Justices award[ing] the presidency to the Republican candidate." The only real question is whether the Court played its part in a politically savvy way. Tushnet doubts this. The justices lost a great deal of support by issuing an opinion that offended rule of law myths too blatantly. They also seem to be gambling too heavily on the success of the Bush presidency to restore their future reputations. Moving beyond this narrow political calculus, 
Tushnet considers the extent to which the opinion expresses a conservative distrust of democracy and an embrace of technological solutions to political problems.

The first three chapters in this part focus on the Court and the super-politicization its decision has generated. But the solution to the problem, if there is one, can be found only in more politics, most obviously the politics involved in appointing the next generation of Supreme Court justices. Cass Sunstein frames the issue against the larger context of the Rehnquist Court's efforts to revolutionize constitutional doctrine. Given the Rehnquist Court's general tendency to denigrate the legitimacy of democratic solutions, the Senate has a responsibility to assure the appointment of justices who will demonstrate greater appreciation of the virtues of political decision making. But this would have been true even if Bush v. Gore had not been decided. He denies that this case should fundamentally change the Senate's approach to the process of "advice and consent."

Bruce Ackerman disagrees. The Court's intervention in the presidential election places an unprecedented constitutional obligation on the Senate. The Supreme Court nominations of presidents are normally entitled to substantial deference because the president has a direct connection to the national electorate. But Bush v. Gore has disturbed this electoral relationship, transforming the Senate into the only popularly elected institution that can control a runaway Court. During the current period of constitutional disequilibrium, the Senate should exercise its authority to prevent any new appointments to the Court. It should require President Bush to demonstrate that he can win the election of 2004 fair and square before allowing his Supreme Court nominees to determine the future direction of constitutional development.

Jack Balkin sets this debate in a larger comparative context. If America had operated under a parliamentary system, the problematic outcome of 2000 would quickly generate a call for new elections, permitting the selection of a leader with a clearer democratic man- 
date. But the American system operates on a fixed electoral calendar. This means that legitimacy questions will recur repeatedly over the next four years. Sometimes, as in the case of judicial appointments, the issues will return to the very surface of public argument, but they will never be entirely absent from other debates as well. Scratch the surface of most normal conflicts and you will find anxieties about constitutional legitimacy. The terrorist attacks of September II, 200I, have given George W. Bush a remarkable opportunity to resolve doubts about his leadership. But as the examples of Lyndon Johnson and George H. W. Bush suggest, a warlike foreign policy is no cure-all for domestic political predicaments. The legitimacy question will remain a part of the debate framing the elections of 2002 and 2004. The enduring verdict on Bush v. Gore will very much depend on who wins these elections.

The contributors to this book regard these chapters as a small part of this larger process of democratic resolution. The first wave of books on the election crisis were written in a rush during the first few weeks after the decision. We decided to take more time to think the issues through. Most of us came to New Haven, Connecticut, for a weekend of intensive discussion in late April 200I. Sustained dialogue probably sharpened the disagreements expressed by the assembled company, but it enabled everybody to hear the best arguments from the other side(s) before returning home to begin writing.

This "talkfest" - as the participants came to call it-not only permitted the essayists to transcend a variety of knee-jerk reactions. It has also allowed them to write a much more unified book. Before putting pen to paper, each writer knew where his or her contribution fit into the larger conversation-yielding a complex whole that is larger than the sum of its parts.

None of us suppose that this book represents anything like the last word. But we do hope it helps move the debate beyond instant analysis and encourages Americans to recognize that the troubling questions raised by Bush v. Gore will be with all of us for a long time to come. 
